Bangladesh J. Bot. 49(1): 47-54, 2020 (March)

\title{
CHROMIUM BIOACCUMULATION POTENTIAL OF BACILLUS CEREUS ISOLATED FROM RHIZOSPHERES OF TAGETES MINUTA L.
}

\author{
Kulsoom Akhter, Tahseen Ghous ${ }^{1}$, Zain-Ul-Abdin $^{*}$, Saiqa Andeeb ${ }^{2}$, \\ Muhammad Naeem Ahmed and Basharat Hussain \\ Department of Chemistry, University of Azad Jammu and Kashmir, \\ Muzaffarabad-13100, Pakistan
}

Keywords: Rhizobacteria, Bioaccumulation, Bacillus cereus, Tagetes minuta

\begin{abstract}
Two metal resistant Bacillus cereus strains (AVP12 and NC7401) isolated from metal polluted and nonpolluted rhizospheres of Tagetes minuta were examined for $\mathrm{Cr}(\mathrm{VI})$ bioaccumulation potential. It was found that the strains have potential to survive even at metal concentration of $300 \mathrm{mg} / \mathrm{l}$. The per cent removal capacity of $\mathrm{Cr}(\mathrm{VI})$ by AVP12 and NC7401 strains was analyzed as a function of environmental factors including $\mathrm{pH}$, incubation time and biosorbate concentration. The optimum $\mathrm{pH}$ was found to be 5 andwas selected for further studies. Both Langmuir and Freundlich isotherm models were found suitable for description of $\mathrm{Cr}(\mathrm{VI})$ bioaccumulation. The maximum $\mathrm{Cr}(\mathrm{VI})$ bioaccumulation capacity by Bacillus cereus AVP12 and Bacillus cereus NC7401 strains isolated from polluted rhizosphere was 181.0 and $107.5 \mathrm{mg} / \mathrm{l}$, respectively while maximum $\mathrm{Cr}(\mathrm{VI})$ bioaccumulation capacity by Bacillus cereus AVP12 and Bacillus cereus NC7401 strains isolated from non-polluted rhizosphere was 92.59 and $62.11 \mathrm{mg} / \mathrm{l}$, respectively. Both types of rhizobacterial strains, especially isolated from metal polluted rhizospheres could serve as economical and ecofriendly bioaccumulating agents for removal of $\mathrm{Cr}(\mathrm{VI})$.
\end{abstract}

\section{Introduction}

The contamination of environment by the heavy metals has become a serious threat to the present world due to toxicity, less solubility in biota, indefinitely persistent and non-degradable nature of the heavy metals (Watson et al. 2016). The urbanization and extensive development of the industries increased the discharge level of the toxic heavy metals into the environment. The toxic heavy metals discharge into the environment contaminated the natural water resources including surface as well as ground water and soil; subsequently these toxic heavy metals enter into the food chain (Förstner and Wittmann 2012). Cr(VI) is one of the highly toxic and industrially originated heavy metals which enters into the environment from the unregulated disposal of $\mathrm{Cr}(\mathrm{VI})$ containing effluents by several industries including leather tanning, chrome plating, alloy manufacturing and dye producing industries (Nzeve 2015). Cr(VI) causes serious pathological changes in liver, lungs and kidneys. It also causes respiratory inflammation, bronchial spasm, anaphylactic reactions and lungs cancer. Chronic exposure to $\mathrm{Cr}(\mathrm{VI})$ causes perforation in nose septum (Tou et al. 2017). Though, various techniques have been developed for the removal of $\mathrm{Cr}(\mathrm{VI})$ from the environment but these techniques are expensive, high energy demanding and generate toxic sludge (Cieślik et al. 2015). Bioaccumulation including the use of bacteria and other microbes is an alternative, which is eco-friendly, cost effective and efficient biological method for removal of the toxic heavy metals (Thakur et al. 2016). The high population of bacteria is present in the rhizospheres with great diversity and activity. These rhizobacteria have

*Author for correspondence: <zainulabdinchm@gmail.com>. ${ }^{1}$ Department of Chemistry, Mirpur University of Science and Technology, Mirpur 10250, Pakistan. ${ }^{2}$ Department of Zoology, University of Azad Jammu and Kashmir, Muzaffarabad-13100, Pakistan. 
symbiotic relationship with the plants and at high metal concentration, they tolerate and accumulate the toxic heavy metals for their survival under metal stressed conditions through the formation of complexes by expression of metal binding proteins like metallothioneins or phytochelatins (Ali et al. 2013). Many genes have been identified which involve in detoxification, tolerance or in uptake of the toxic heavy metal ions (Thakur et al. 2016). These capabilities enable them to remove the heavy metals from environment up to the levels which are no longer harmful for human health.

The present work was aimed to analyze $\mathrm{Cr}(\mathrm{VI})$ per cent removal capacity and bioaccumulation potential of the two rhizobacterial strains (Bacillus cereus AVP12 and Bacillus cereus NC7401) isolated from the rhizospheres of Tagetes minuta growing in metal polluted as well as non-polluted soil. Present authors investigated per cent removal capacity and bioaccumulation potential of these strains for the removal of $\mathrm{Cr}(\mathrm{VI})$ from the environment and compared the results in different rhizospheric environment. The minimum inhibitory concentration (MIC) of $\mathrm{Cr}(\mathrm{VI})$ was also determined for both the strains.

\section{Materials and Methods}

Tagetes minuta along with soil adhered to roots was picked up from polluted area with effluents of automobile workshops as well as from non-polluted area. Roots of each sample plant were suspended in sterile ringer's solution separately and the spread plates were prepared on nutrient agar medium for bacterial growth at $37^{\circ} \mathrm{C}$ for $24 \mathrm{hrs}$. The discrete colonies were picked up and inoculated in to the nutrient broth to grow cultures at $37^{\circ} \mathrm{C}$ in a shaking incubator for $24 \mathrm{hrs}$. This process was repeated three times unless the pure colonies were obtained (Fig. 1).

Root adhered soil of both samples was collected and ground into powder form. About $1 \mathrm{~g}$ of the grinded sample soil was dissolved in $25 \mathrm{ml}$ deionized water by constant shaking. The metal concentration of the supernatant was analyzed in Pakistan Institute of Nuclear Science and Technology, Islamabad.

The MIC of the isolates was investigated using well diffusion method with increasing concentration of $\mathrm{Cr}(\mathrm{VI})$ from $50-300 \mathrm{mg} / \mathrm{l}$. The wells $(7 \mathrm{~mm}$ in diameter and $4 \mathrm{~mm}$ in depth) were made in each plate containing microbes inoculated nutrient agar medium and $100 \mu \mathrm{Cr}(\mathrm{VI})$ solutions were added in the wells in triplicates, which were then incubated at $37^{\circ} \mathrm{C}$ for $24 \mathrm{hrs}$ and the zone of inhibition (ZOI) was analyzed. The isolates growing in $\mathrm{Cr}(\mathrm{VI})$ concentration were initially identified by their colony morphology, gram staining, acid and gas production, carbohydrate (glucose, lactose and sucrose) fermentation, urease, catalase production and starch hydrolysis using standard methods as described by Cappuccino and Sherman (2008) (Fig. 2). Further identification was carried out at Macrogen Inc. Seoul, Korea by 16S rRNA gene sequencing using universal primer 518F (5'- CCAGCAGCCGCGGTAATACG-3'). For proper strains identification, the obtained sequences were matched with closely related sequences of the known taxonomic information in the data bank at NCBI website (http://www.ncbi.nlm.nih.gov/ BLAST).

Bacillus cereus AVP12 and Bacillus cereus NC7401 isolated and identified from both polluted as well as non-polluted rhizospheres of Tagetes minuta were selected for analysis of per cent removal efficiency of $\mathrm{Cr}(\mathrm{VI})$ (Fig. 1). In a screw capped sterilized test tube, $5 \mathrm{ml}$ refreshed culture was mixed with $1 \mathrm{ml} \mathrm{Cr}(\mathrm{VI})$ solution, agitated at $150 \mathrm{rpm}$ in a shaking incubator at $37^{\circ} \mathrm{C}$. The sample was then centrifuged at $13000 \mathrm{rpm}$ for $5 \mathrm{~min}$ and supernatant was analyzed for the estimation of $\mathrm{Cr}(\mathrm{VI})$ concentration spectrophotometrically using diphenylcarbazide method (Jankiewicz and Ptaszynski 2005) (double beam spectrophotometer, Shimadzu UV 1800). A control was also set containing nutrient broth medium along with $\mathrm{Cr}(\mathrm{VI})$ solution keeping all other conditions same except bacterial culture. Each test was performed in triplicates and average value 
was taken as result. The effect of $\mathrm{pH}$, incubation time and initial biosorbate concentration on removal efficiency of each strain was determined and the percent removal efficiency (R) of $\mathrm{Cr}(\mathrm{VI})$ was calculated using equation 1 .

$$
\% \mathrm{R}=\frac{A i-A E}{A i} \times 100
$$

where $\% \mathrm{R}$ is the $\mathrm{Cr}(\mathrm{VI})$ per cent removal efficiency, Ai and Ae are the absorbance at $544 \mathrm{~nm}$ before and after $\mathrm{Cr}(\mathrm{VI})$ bioaccumulation.

Bacillus cereus AVP12 and Bacillus cereus NC7401 strains were cultivated aerobically in the sterile nutrient broth at $37^{\circ} \mathrm{C}$ and $150 \mathrm{rpm}$ for $24 \mathrm{hrs}$. The cells were harvested by centrifugation and the obtained pellets were dried at $65^{\circ} \mathrm{C}$ for 20 hand stored at $-20^{\circ} \mathrm{C}$. Four $\mathrm{mg}$ of the dried cells were mixed with $1 \mathrm{ml}$ of the sterile $\mathrm{Cr}(\mathrm{VI})$ solution in screw capped tubes, agitated on a shaking incubator at $150 \mathrm{rpm}$ at $37^{\circ} \mathrm{C}$ for $1 \mathrm{hr}$, centrifuged and supernatant was used for spectrophotometric determination of $\mathrm{Cr}(\mathrm{VI})$ concentration before and after bioaccumulation (Fig. 1). The amount of metal adsorbed on the bacterial biomass was calculated by equation 2 .

$$
\mathrm{qe}=\frac{(\mathrm{Co}-\mathrm{Ce}) \mathrm{V}}{\mathrm{M}}
$$

Where qe is the amount of the metal accumulated in $\mathrm{mg} / \mathrm{g}$ of the bacterial biomass at equilibrium, $\mathrm{C}_{\mathrm{o}}$ is the initial metal ion concentration and $\mathrm{Ce}$ is the final metal ion concentration in $\mathrm{mg} / \mathrm{l}$, respectively. $\mathrm{V}$ is the volume of the solution taken in $\mathrm{L}$ and $\mathrm{M}$ is the amount of the biosorbent used in $\mathrm{g}$.

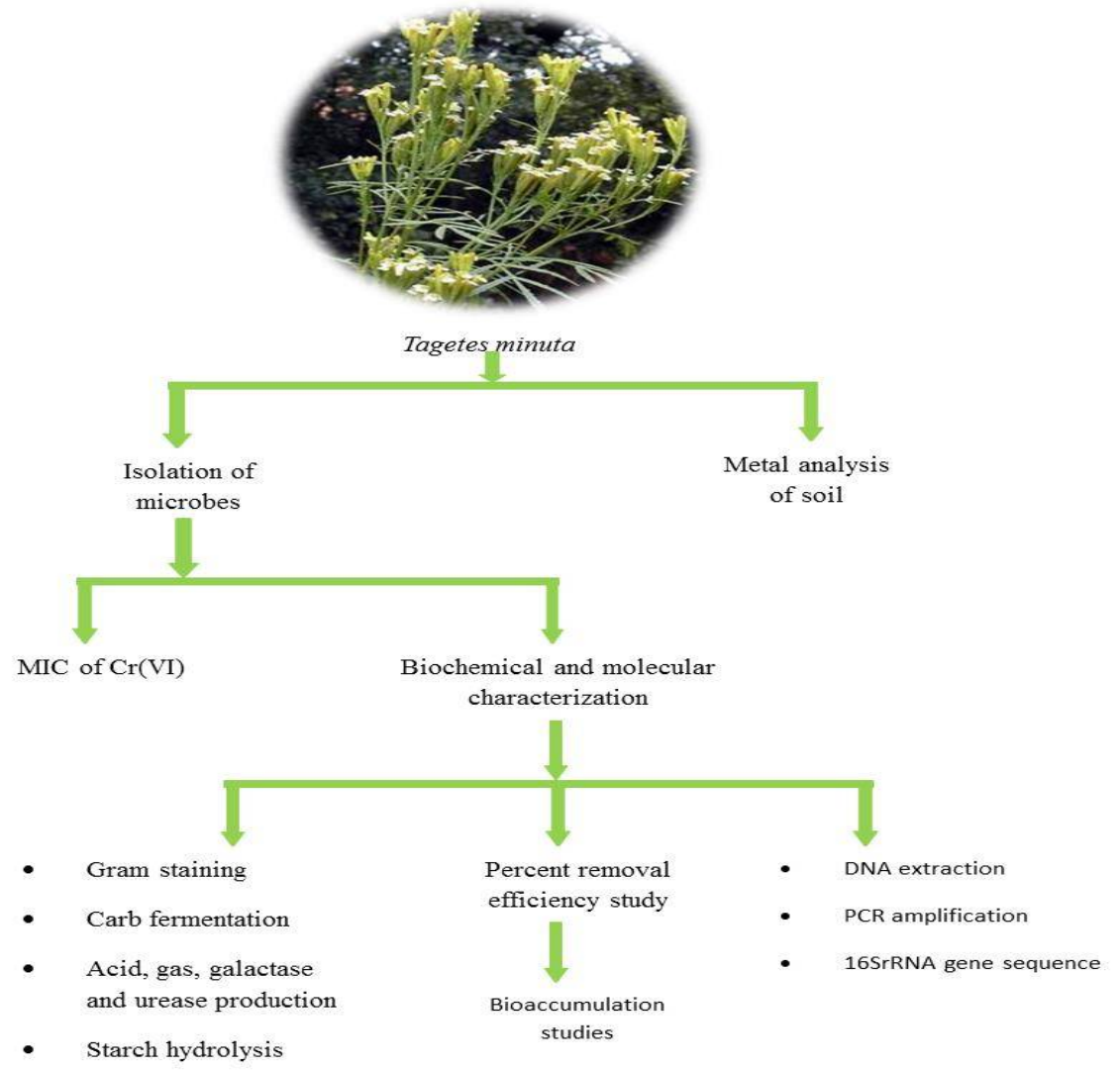

Fig. 1. Experimental pathway for the determination of $\mathrm{Cr}(\mathrm{VI})$ bioaccumulation potential. 


\section{Results and Discussion}

Atomic absorption spectrophotometric analysis of the soil sample collected from polluted rhizosphere showed the presence of $107.7 \mathrm{ppb} \mathrm{Ni}(\mathrm{II})$ and $8.34 \mathrm{ppb} \mathrm{Cd}(\mathrm{II})$ and $\mathrm{Cr}(\mathrm{VI})$ was not detected, whereas only $\mathrm{Cd}(\mathrm{II})$ was detected at a very low concentration of $0.87 \mathrm{ppb}$ in the sample collected from non-polluted rhizospheric soil.

For minimum inhibitory concentrations (MICs), the results of the adopted well diffusion method showed that all the strains were capable to grow even at high concentration of $\mathrm{Cr}(\mathrm{VI})$ (300 $\mathrm{mg} / \mathrm{l})$. The colonies of the bacterial isolates were large, flat and irregular with undulate margin. Using compound microscope, the strains were seen as rod shaped, motile and gram positive. The biochemical characterizations showed that the isolates fermented glucose, fructose and lactose were involved in the production of acid and the enzyme catalase, while no gas production was observed. Similarly, no urease production and starch hydrolysis were observed. BLAST (Basic Local Alignment Search Tool) analysis of 16SrRNA gene sequence showed $99 \%$ genetic similarity of one bacterium with rRNA sequence of Bacillus cereus AVP12 (Accession number KF527826.1) and the other with Bacillus cereus NC7401 (Accession number AB861980.1) both isolated from polluted as well as non-polluted rhizospheres (Fig. 2).

$\mathrm{pH}$ of $100 \mathrm{mg} / \mathrm{l} \mathrm{Cr}(\mathrm{VI})$ solutions was adjusted in the range of $5-9$ prior to the addition of the biosorbent. Fig. 3 (A and B) demonstrates the effect of $\mathrm{pH}$ on metal binding behavior of the studied bacterial strains. All the strains showed maximum percent removal efficiency for $\mathrm{Cr}(\mathrm{VI})$ at $\mathrm{pH} 5$ and lowest at $\mathrm{pH}$ 9. The metal binding behavior of the bacterial strain was dependent on the chemical composition of its cell wall. Results of the studies are in good agreement with the findings reported by Wang et al. (2010) that in acidic medium, bacterial cell wall becomes positively charged resulting in maximum binding ability for chromate ions.
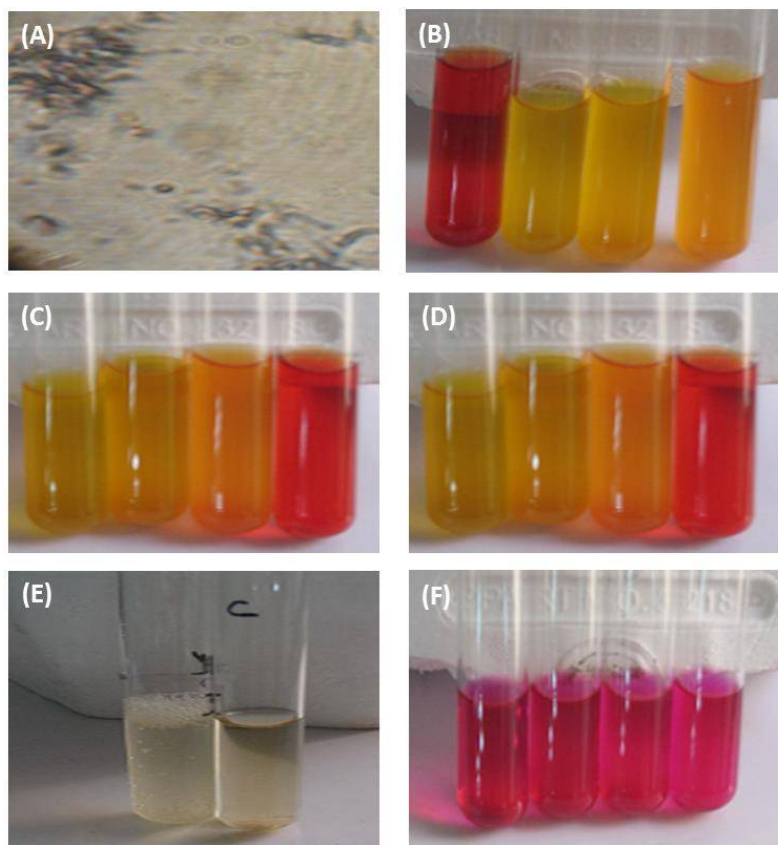

Fig. 2. Different biochemical tests for Bacillus species (A) gram staining: (B) glucose fermentation,

(C) lactose fermentation, (D) sucrose fermentation, (E) urease test and (F) catalase test. 
At acidic $\mathrm{pH}$, the functional groups present on the cell surface become protonated and their binding capacity for metal ions such as chromates would increase due to electrostatic interaction (Ibrahim et al. 2016).

(A)

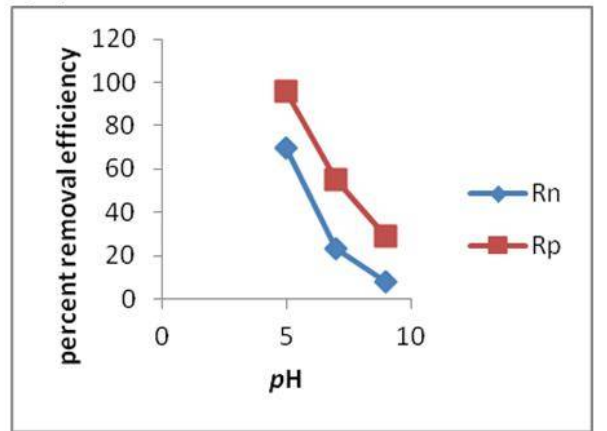

(B)

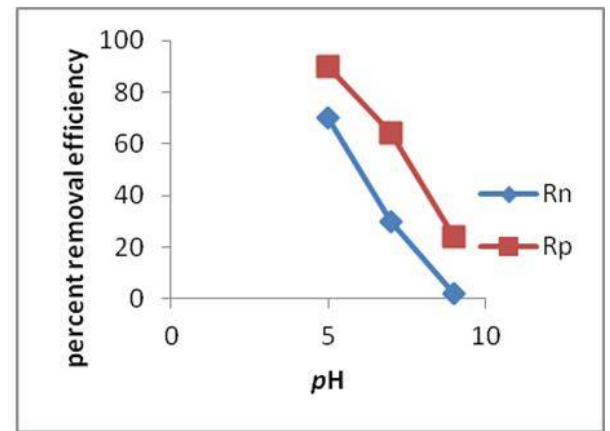

Fig. 3. Effect of $\mathrm{pH}$ on the per cent metal removal efficiency by Bacillus cereus strains: (A) Bacillus cereus AVP12 and Bacillus cereus NC7401 (metal conc. was $100 \mathrm{mg} / \mathrm{l}$ and incubation time was $24 \mathrm{hrs}$ ). $\mathrm{Rn}=$ Bacteria isolated from non-polluted rhizosphere and $\mathrm{Rp}=$ Bacteria isolated from polluted rhizosphere.

The effect of incubation time on $\mathrm{Cr}(\mathrm{VI})(100 \mathrm{mg} / \mathrm{l})$ uptake by both the Bacillus strains was investigated at $37^{\circ} \mathrm{C}$ with intervals of $4,24,48,72$ and $96 \mathrm{hrs}$. Three $\mathrm{ml}$ of the aliquot was removed after each time interval. Fig. 4 (A and B) represents per cent $\mathrm{Cr}(\mathrm{VI})$ removal efficiency of the strains. For strains isolated from non-polluted area, almost 50\% $\mathrm{Cr}(\mathrm{VI})$ was removed after an incubation time of $4 \mathrm{hrs}$. The removal efficiency for $\mathrm{Cr}(\mathrm{VI})$ increased with the increase in incubation time and reached up to its maximum i.e., $80 \%$ at $48 \mathrm{hrs}$ and then it changed very slightly with further increase in incubation time. However, per cent removal efficiency for $\mathrm{Cr}(\mathrm{VI})$

(A)

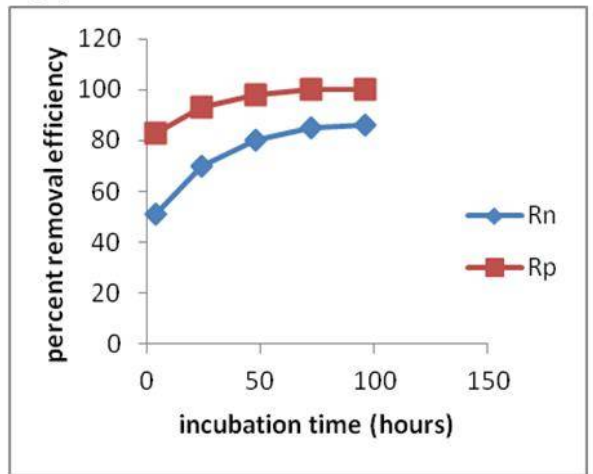

(B)

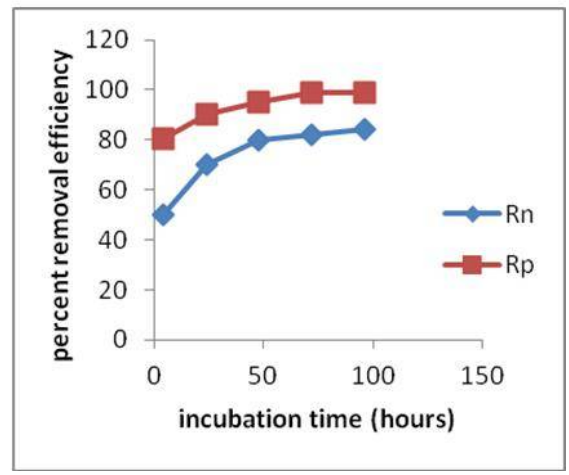

Fig. 4. Effect of incubation time on the per cent metal removal efficiency by: (A) Bacillus cereus strains B. cereus AVP12, (B) Bacillus cereus NC7401 (metal conc. $100 \mathrm{mg} / \mathrm{l}, \mathrm{pH} 5$ ) $\mathrm{Rn}=$ Bacteria isolated from non-polluted rhizosphere and $\mathrm{Rp}=$ Bacteria isolated from polluted rhizosphere.

was comparatively high for the strains isolated from contaminated rhizospheres, which was significant after 4 hrs incubation time i.e, 80.7 and $83 \%$ for Bacillus cereus AVP12 and Bacillus cereus NC7401, respectively and it reached up to $100 \%$ at $24 \mathrm{hrs,} \mathrm{after} \mathrm{which} \mathrm{an} \mathrm{equilibrium} \mathrm{was}$ established. The incubation time of $24 \mathrm{hrs}$ was selected as most suitable time, where $\mathrm{Cr}(\mathrm{VI})$ removal efficiency of all the strains was found to be significant. 
The effect of initial $\mathrm{Cr}(\mathrm{VI})$ concentration on the per cent removal efficiency of $\mathrm{Cr}(\mathrm{VI})$ by Bacillus cereus AVP12 and Bacillus cereus NC7401 was investigated using a range of metal concentration from $50-250 \mathrm{mg} / \mathrm{l}$ for biosorbent-biosorbate contact duration of $24 \mathrm{hrs}$ at $37^{\circ} \mathrm{C}$. The experimental results are presented in Fig. 5 (A and B) which shows that the removal efficiency for $\mathrm{Cr}(\mathrm{VI})$ was high at low concentration and as initial concentration was increased, the removal efficiency decreased. At low concentration, $\mathrm{Cr}(\mathrm{VI})$ was accumulated more quickly to the available sites. However, as concentration increased $\mathrm{Cr}(\mathrm{VI})$ remains in the solution due to the insufficiently available binding sites.
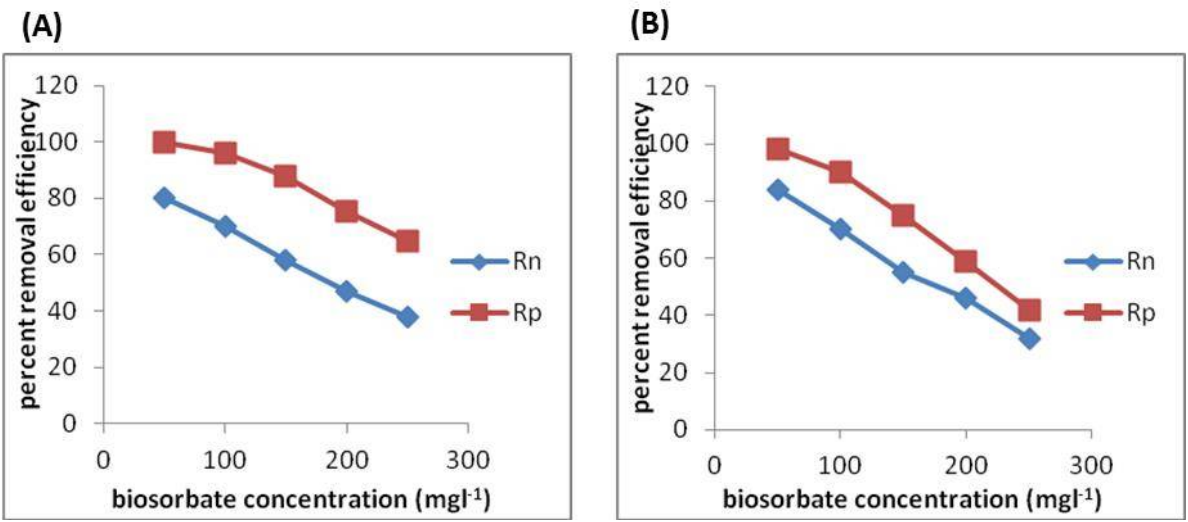

Fig. 5. Effect of biosorbate concentration on per cent metal removal efficiency by: (A) B. cereus strains (B) cereus AVP12 and Bacillus cereus NC7401 (pH 5 and incubation time $24 \mathrm{hrs).} \mathrm{Rn} \mathrm{=} \mathrm{Bacteria} \mathrm{isolated}$ from non-polluted rhizosphere and $\mathrm{Rp}=$ Bacteria isolated from polluted rhizosphere

The bioaccumulation capacity of Bacillus cereus AVP12 and Bacillus cereus NC7401 increased rapidly with the increase in $\mathrm{Cr}(\mathrm{VI})$ initial concentration, as rate of bioaccumulation is the function of metal concentration. Fig. 6 (A and B) shows that as $\mathrm{Cr}(\mathrm{VI})$ concentration was increased from $50-250 \mathrm{mg} / \mathrm{l}$, the loading capacity for the two strains isolated from non-polluted

(A)

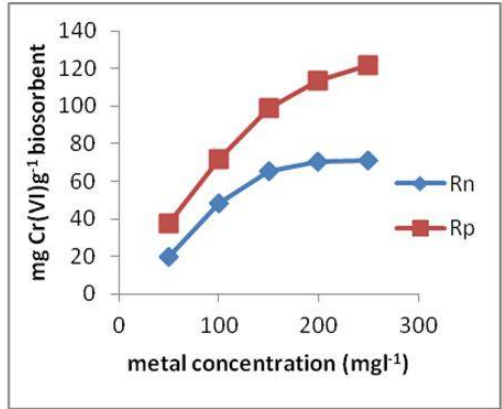

(B)

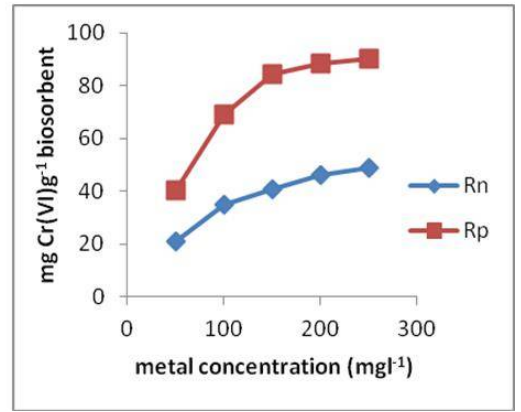

Fig. 6. Bioaccumulation capacity shown by: (A) Bacillus cereus AVP12 and (B) Bacillus cereus NC7401 ( $\mathrm{pH} 5$ and incubation time $24 \mathrm{hrs}$ ). $\mathrm{Rn}=$ Bacteria isolated from non-polluted rhizosphere, $\mathrm{Rp}=\mathrm{Bacteria}$ isolated from polluted rhizosphere.

rhizosphere increased from 20 and $21 \mathrm{mg} / \mathrm{g}$ to 71.25 and $49 \mathrm{mg} / \mathrm{g}$, while $\mathrm{Cr}(\mathrm{VI})$ loading capacity for the two strains isolated from polluted rhizosphere increased from 37.5 and $40.5 \mathrm{mg} / \mathrm{g}$ to 121.87 and $90 \mathrm{mg} / \mathrm{l}$, respectively. A very slow increase was observed after the concentration $150 \mathrm{mg} / \mathrm{l}$. It was found by further extending the graph of the increase in bioaccumulation of $\mathrm{Cr}(\mathrm{VI})$ that an 
equilibrium may establish at concentration greater than $300 \mathrm{mg} / \mathrm{l}$. Many genes have been identified which are involved in detoxification, tolerance or in uptake of the heavy metal ions. It is clearly demonstrated from the Fig. 6 that Bacillus cereus strains isolated from metal polluted rhizosphere showed higher bioaccumulation capacity which might be due to the over expression of the metal sequestering proteins including metal-lothioneinsin these strains, so that their survival become possible under such metal stressed environment.

Langmuir and Freundlich isotherm models constants for bioaccumulation of $\mathrm{Cr}(\mathrm{VI})$ on Bacillus cereus strains are given in Table 1. The linearized Freundlich equation is given as:

$$
\mathrm{q}_{\mathrm{eq}}=\mathrm{K}_{\mathrm{f}} \mathrm{C}_{\mathrm{eq}}{ }^{1 / \mathrm{n}}
$$

where $\mathrm{q}_{\mathrm{eq}}$ is the amount of $\mathrm{Cr}(\mathrm{VI})$ adsorbed at equilibrium, Ceq is the equilibrium solution concentration in $\mathrm{mg} / \mathrm{l}, \mathrm{K}_{\mathrm{f}}$ is the predicted amount in $\mathrm{mg}$ of $\mathrm{Cr}(\mathrm{VI})$ removed per $\mathrm{g}$ of the dry cells at an equilibrium concentration of $1 \mathrm{mg} / \mathrm{l} 1 / \mathrm{n}$ is the slope of the isotherm. High $\mathrm{K}_{\mathrm{f}}$ values of 39.17 and 12.95 for Bacillus cereus AVP12 and Bacillus cereus NC7401, respectively indicated that the strains isolated from polluted rhizospheres bioaccumulated $\mathrm{Cr}(\mathrm{VI})$ more efficiently than the strains isolated from non-polluted rhizospheres.

Langmuir model was rearranged as:

$$
\mathrm{Qeq}=\mathrm{Q}^{\mathrm{o}} \mathrm{bCeq} / 1+\mathrm{bCeq}
$$

where $\mathrm{Q}^{\mathrm{o}}$ is the maximum adsorption capacity and $\mathrm{b}$ is the Langmuir constant related to the binding affinity of the binding sites. $\mathrm{Q}^{\circ}$ and $\mathrm{b}$ values can be obtained from the linear plot of Ceq/qeq versus Ceq. Langmuir parameters also showed significantly high bioaccumulation capacity $\left(\mathrm{Q}^{\circ}\right)$ of 181 and $107.5 \mathrm{mg} / \mathrm{g}$ for the strains AVP12 and NC7401, respectively isolated from polluted rhizospheres whereas the values of 92.59 and $62.11 \mathrm{mg} / \mathrm{g}$ were obtained for the strains isolated from non-polluted rhizosphere with the same sequence.

Table 1. Isotherm models constants for the adsorption of $\mathrm{Cr}(\mathrm{VI})$ on Bacillus strains.

\begin{tabular}{lllllllll}
\hline \multirow{2}{*}{$\begin{array}{l}\text { B. cereus } \\
\text { strain }\end{array}$} & \multirow{2}{*}{ Rhizosphere } & \multicolumn{3}{c}{ Freundlich } & & \multicolumn{3}{c}{ Langmuir } \\
\cline { 3 - 4 } & & $\mathrm{K}_{\mathrm{F}}(\mathrm{mg} / \mathrm{g})$ & $\mathrm{n}$ & $\mathrm{R}^{2}$ & & $\mathrm{~b}$ & $\mathrm{Q}^{\mathrm{o}}(\mathrm{mg} / \mathrm{g})$ & $\mathrm{R}^{2}$ \\
\hline B. cereus & Polluted & 39.17 & 8.0 & 0.992 & & 2.37 & 181.0 & 0.990 \\
AVP12 & Non-polluted & 6.81 & 2.16 & 0.916 & & 0.75 & 92.59 & 0.986 \\
\multirow{2}{*}{$\begin{array}{l}\text { B. cereus } \\
\text { NC7401 }\end{array}$} & Polluted & 12.95 & 2.5 & 0.912 & & 3.39 & 107.5 & 0.994 \\
& Non-polluted & 5.12 & 2.28 & 0.960 & & 7.53 & 62.11 & 0.998 \\
\hline
\end{tabular}

The strains isolated from both types of rhizospheres of Tagetes minuta showed stronger bioaccumulation capacity, which could be due to the presence of different functional groups like hydroxyl, carboxyl and amine groups, that enabled the Bacillus cereus strains to accumulate the heavy metal $\mathrm{Cr}(\mathrm{VI})$ from aqueous solution. The strains which were isolated from polluted rhizosphere showed higher bioaccumulation potential that could be due to the reason that these strains may have enhanced their metal accumulation capacity by expressing metal sequestering proteins while coming in contact with such metal polluted environment. Due to their high and fast bioaccumulation properties these strains could be a potential source for cleaning up surface water or post-treatment of wastewater.

\section{Acknowledgements}

Authors are grateful to Higher Education Commission, Pakistan for financial support. 


\section{References}

Ali H, Khan E, Sajad MA 2013. Phytoremediation of heavy metals - Concepts and applications. Chemosphere 91(7): 869-881.

Cappuccino J and Sherman N 2008. Microbiology: A Laboratory Manual, Pearson/Benjamin Cummings. San Francisco, US.

Cieślik BM, Namieśnik J and Konieczka P 2015. Review of sewage sludge management: standards, regulations and analytical methods. Journal of Cleaner Production 90: 1-15.

Förstner U and Wittmann GT 2012. Metal pollution in the aquatic environment, Springer Science \& Business Media.

Ibrahim WM, Hassan AF and Azab YA 2016. Biosorption of toxic heavy metals from aqueous solution by Ulva lactuca activated carbon. Egyptian Journal of Basic and Applied Sciences 3(3): 241-249.

Jankiewicz B and Ptaszynski B 2005. Determination of chromium in soil of£ ód $\ddot{Y}$ gardens. Pol J Environ Stud. 14: 869-875.

Nzeve JK 2015. Assessment of heavy metal contamination in Masinga Reservoir, Kenya, PhD Thesis, Kenyatta University, Kenya.

Thakur S, Singh L, Wahid ZA, Siddiqui MF, Atnaw SM and Din MF 2016. Plant-driven removal of heavy metals from soil: uptake, translocation, tolerance mechanism, challenges, and future perspectives. Environmental Monitoring and Assessment 188(4): 206.

Tou F, Yang Y, Feng J, Niu Z, Pan H, Qin Y, Guo X, Meng X, Liu M and Hochella MF 2017. Environmental risk implications of metals in sludges from waste water treatment plants: the discovery of vast stores of metal-containing nanoparticles. Environmental Science \& Technology 51(9): 4831-4840.

Wang XS, Li Y, Huang LP and Chen J 2010. Adsorption of $\mathrm{Cr}$ (VI) from aqueous solutions by Staphylococcus aureus biomass. Clean-Soil, Air, Water 38(5-6): 500-505.

Watson SCL, Paterson DM, et al 2016. A conceptual framework for assessing the ecosystem service of waste remediation: In the marine environment. Ecosystem Services 20: 69-81.

(Manuscript received on 3 October, 2018; revised on 14 April, 2019) 